\title{
Z prawnej problematyki obowiązków nabywcy nieruchomości rolnej wynikających z art. 2b ustawy o kształtowaniu ustroju rolnego
}

\section{Wstęp}

Nowelizacja ustawy z 11 kwietnia 2003 r. o kształtowaniu ustroju rolnego ${ }^{1}$, dokonana ustawą z 14 kwietnia 2016 r. o wstrzymaniu sprzedaży nieruchomości Zasobu Własności Rolnej Skarbu Państwa oraz o zmianie niektórych ustaw ${ }^{2}$ (weszła w życie 30 kwietnia 2016 r.), wprowadziła do polskiego systemu prawa rolnego dwa obowiązki nabywcy nieruchomości rolnej o fundamentalnym znaczeniu: nakaz prowadzenia gospodarstwa rolnego, w skład którego weszła nabyta nieruchomość rolna, przez okres co najmniej 10 lat od dnia nabycia przez niego tej nieruchomości, a w przypadku osoby fizycznej prowadzenia tego gospodarstwa osobiście (art. 2b ust. 1 u.k.u.r.) oraz zakaz zbywania nabytej nieruchomości lub oddawania jej w posiadanie innym podmiotom w ramach tego samego 5-letniego okresu (art. 2b ust. 2 u.k.u.r.). Kolejna nowelizacja u.k.u.r. dokonana ustawą z 26 kwietnia

* Uniwersytet Jagielloński w Krakowie.

${ }^{1}$ Ustawa z 11 kwietnia 2003 r. o kształtowaniu ustroju rolnego (t.j. Dz. U. z 2019 r., poz. 1362 ze zm.; dalej: u.k.u.r.).

${ }^{2}$ Ustawa z 14 kwietnia 2016 r. o wstrzymaniu sprzedaży nieruchomości Zasobu Własności Rolnej Skarbu Państwa oraz o zmianie niektórych ustaw (t.j. Dz. U. z 2018 r., poz. 868 ze zm.). 
2019 r. o zmianie ustawy o kształtowaniu ustroju rolnego oraz niektórych innych ustaw ${ }^{3}$ (weszła w życie 26 czerwca 2019 r.), pozornie liberalizując reżim publicznoprawnej kontroli obrotu nieruchomościami rolnymi (m.in. poprzez skrócenie wskazanego wyżej 10-letniego okresu do 5 lat), w rzeczywistości zwiększyła praktyczne znaczenie obu tych obowiązków ${ }^{4}$, przyczyniając się zarazem do powstania wątpliwości co do właściwej interpretacji norm prawnych, z których obowiązki te wynikają ${ }^{5}$. W literaturze zwrócono uwagę na możliwość zróżnicowanej wykładni tych norm, wyodrębniając restrykcyjny i liberalny kierunek ich interpretacji ${ }^{6}$. Również sygnały płynące z praktyki wskazują, że kwestia ustalenia właściwego zakresu obowiązków nabywcy nieruchomości rolnej wynikających z art. 2 b u.k.u.r. stanowi obecnie najpoważniejszy - obok delimitacji samego pojęcia „,nieruchomość rolna" - problem interpretacyjny, przed jakim stoją organy i instytucje sto-

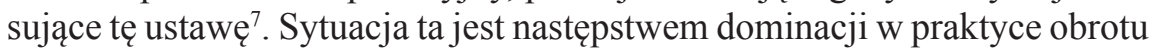
restrykcyjnego kierunku wykładni przepisów art. 2b u.k.u.r., upowszechnianego zwłaszcza przez Krajowy Ośrodek Wsparcia Rolnictwa (KOWR), $\mathrm{i}$ to w sposób tak radykalny, iż wywołuje on uzasadnione obawy stosowania przez tę instytucję wykładni contra legem.

Zasadniczym celem badań prezentowanych w niniejszym artykule jest rozstrzygniecie niektórych wątpliwości związanych z właściwą interpretacją przepisów art. $2 \mathrm{~b}$ u.k.u.r. Realizacja tego celu badawczego wymaga głównie przedstawienia podstawowych założeń dominującego w obrocie nieruchomościami kierunku wykładni art. 2 b u.k.u.r. Ich charakterystyka pozwoli zarówno na ukazanie wielu praktycznych problemów, jakie wynikają z przyjęcia tego kierunku wykładni, jak i na określenie, do jakiego stopnia

${ }^{3}$ Ustawa z 26 kwietnia 2019 r. o zmianie ustawy o kształtowaniu ustroju rolnego oraz niektórych innych ustaw (Dz. U. poz. 1080).

${ }^{4}$ P.A. Blajer, Umowy działowe dotyczące nieruchomości rolnych po wejściu w życie ustawy $z$ dnia 26 kwietnia 2019 r. o zmianie ustawy o ksztaltowaniu ustroju rolnego oraz niektórych innych ustaw, „Krakowski Przegląd Notarialny” 2019, nr 3, s. 52-53.

${ }^{5}$ A. Bieranowski, Uwagi o błędnym dekodowaniu zakazu zbywania własności nieruchomości rolnej, „Rejent” 2019, nr 8, s. 112.

${ }^{6}$ P.A. Blajer, Umowa sprzedaży nieruchomości rolnej po wejściu w życie ustawy z dnia 26.04.2019 r. o zmianie ustawy o ksztaltowaniu ustroju rolnego oraz niektórych innych ustaw, „Rejent” 2019, nr 12, s. 120.

${ }^{7}$ Doskonałą okazję do wymiany doświadczeń przez przedstawicieli teorii prawa rolnego i praktyki obrotu w zakresie aktualnych problemów związanych ze stosowaniem przepisów u.k.u.r. stanowiła zorganizowana 26 listopada 2020 r. przez Zakład Prawa Rolnego, Żywnościowego i Ochrony Środowiska Wydziału Prawa i Administracji Uniwersytetu im. Adama Mickiewicza w Poznaniu oraz Izbę Notarialną w Poznaniu konferencja naukowa „Obrót nieruchomościami rolnymi - teoria i praktyka". Wiele z zaprezentowanych podczas niej poglądów i tez stanowiło bezpośrednią inspirację dla rozważań prowadzonych w niniejszym artykule. 
jest on zgodny z fundamentalnymi zasadami Konstytucji RP oraz prawem Unii Europejskiej. Powinno to umożliwić sformułowanie wniosków de lege ferenda co do zasadności dalszego utrzymywania regulacji art. $2 b$ u.k.u.r. w jej obecnym kształcie w polskim systemie prawa rolnego.

\section{Wybrane problemy praktyczne związane ze stosowaniem art. 2b u.k.u.r. w obecnym brzmieniu oraz z przyjęciem restrykcyjnego kierunku wykładni wynikających z niego przepisów}

\subsection{Problem właściwego ustalenia treści obowiązku prowadzenia gospodarstwa rolnego (art. $2 b$ ust. 1 u.k.u.r.)}

Głównym problemem interpretacyjnym związanym ze stosowaniem art. $2 \mathrm{~b}$ ust. 1 u.k.u.r. w praktyce jest prawidłowe ustalenie zakresu nałożonego na nabywcę nieruchomości rolnej „obowiązku prowadzenia gospodarstwa rolnego". Pewnych wskazówek dostarcza w tym względzie definicja pojęcia „osobiste prowadzenie gospodarstwa rolnego”, zawarta w art. 6 ust. 2 pkt 1 u.k.u.r., zgodnie z którą osoba fizyczna osobiście prowadzi gospodarstwo rolne, jeżeli pracuje w tym gospodarstwie oraz podejmuje wszelkie decyzje dotyczące prowadzenia działalności rolniczej w tym gospodarstwie. Treść tej definicji została zrelatywizowana wyłącznie do osób fizycznych, tymczasem obowiązek prowadzenia gospodarstwa rolnego ma charakter powszechny, to znaczy odnosi się również do innych kategorii nabywców nieruchomości rolnych.

W literaturze zauważa się, że obowiązek prowadzenia gospodarstwa rolnego, w skład którego weszła nabyta nieruchomość, a w przypadku osoby fizycznej-obowiązek osobistego prowadzenia takiego gospodarstwa należy ujmować w kategoriach obowiązku prowadzenia działalności rolniczej ${ }^{8}$. Stosownie do art. 2 pkt 3 u.k.u.r. przez prowadzenie działalności rolniczej należy rozumieć prowadzenie działalności wytwórczej w rolnictwie w zakresie produkcji roślinnej lub zwierzęcej, w tym produkcji ogrodniczej, sadowniczej i rybnej ${ }^{9}$. To niewątpliwie słuszne spostrzeżenie wymaga jednak doprecyzowania. Kryterium prowadzenia gospodarstwa rolnego oraz

${ }^{8}$ D. Łobos-Kotowska, M. Stańko, Komentarz do art. 2b, teza 4, w: eidem, Ustawa o ksztattowaniu ustroju rolnego. Komentarz, Warszawa 2019.

${ }^{9}$ Istotne znaczenie ma okoliczność, że działalność rolnicza ma mieć charakter kwalifikowanej działalności „wytwórczej”, co oznacza, że np. utrzymywanie gruntów jedynie w dobrej kulturze rolnej poprzez ich ugorowanie nie stanowi prowadzenia działalności rolniczej w rozumieniu u.k.u.r. 
kryterium prowadzenia działalności rolniczej stanowią dwa odrębne wymogi podmiotowe formułowane wobec osób władających nieruchomościami rolnymi w polskim systemie prawa rolnego. Oba te pojęcia mają długą i zasadniczo autonomiczną tradycję na płaszczyźnie polskich aktów prawnych, choć związki pomiędzy nimi są oczywiste ${ }^{10}$. W skrócie można stwierdzić, że o ile kryterium prowadzenia działalności rolniczej kładzie akcent na same tylko cechy i atrybuty prowadzonej działalności, o tyle kryterium prowadzenia gospodarstwa rolnego uwzględnia przede wszystkim sprawowanie zarządu nad gospodarstwem rolnym, administrowanie nim ${ }^{11}$. Najbardziej dobitnie znaczenie tego pojęcia oddaje sformułowanie, zgodnie z którym oznacza ono ,wykonywanie zawodu rolnika w gospodarstwie rolnym i tym samym kierowanie nim"12. W tym zresztą kierunku definiowane jest „osobiste prowadzenie gospodarstwa rolnego" zgodnie z powołanym przepisem art. 6 ust. 2 pkt 1 u.k.u.r. ${ }^{13}$

Poczynione spostrzeżenia pozwalają na określenie - choć w sposób nasuwający wiele wątpliwości i zastrzeżen ${ }^{14}$ - na czym polega obowiązek zawarty w art. $2 \mathrm{~b}$ ust. 1 u.k.u.r. w przypadku, gdy nabywcą nieruchomości rolnej jest osoba fizyczna. Nabywca taki powinien przez 5 lat wykonywać zawód rolnika w gospodarstwie rolnym, tj. pracować w nim oraz podejmować wszelkie decyzje dotyczące prowadzenia w gospodarstwie działalności wytwórczej w rolnictwie w zakresie produkcji roślinnej lub zwierzęcej,

${ }^{10}$ Szeroko w tym zakresie: P. Blajer, Koncepcja prawna rolnika indywidualnego w prawie polskim na tle porównawczym, Kraków 2009, s. 225 i n.

${ }^{11}$ E. Gniewek, Nabycie własności gruntów rolnych przez posiadaczy. Podstawowe zagadnienia ustawy o uregulowaniu własności gospodarstw rolnych, Wrocław 1978, s. 52; J. Paliwoda, Problemy prawne uregulowania własności gospodarstw rolnych, Wrocław 1976, s. 31; J.S. Piątowski, Uregulowanie własności gospodarstw rolnych i zmiany w kodeksie cywilnym, „Państwo i Prawo” 1971, nr 8, s. 288.

${ }_{12}$ F. Błahuta, J.S. Piątowski, J. Policzkiewicz, Gospodarstwa rolne. Obrót, dziedziczenie, podziat, Warszawa 1967, s. 99.

${ }^{13}$ Wskazówkę, że ustawodawca odróżnia pojęcie prowadzenia działalności rolniczej od pojęcia prowadzenia gospodarstwa rolnego, stanowi również treść art. 29a ust. 1 pkt 1 ustawy z 19 października 1991 r. o gospodarowaniu nieruchomościami rolnymi Skarbu Państwa (t.j. Dz. U. z 2020 r., poz. 2243), wprowadzonego do tego aktu prawnego również mocą cytowanej ustawy z 14 kwietnia 2016 r. o wstrzymaniu sprzedaży nieruchomości Zasobu Własności Rolnej Skarbu Państwa oraz o zmianie niektórych ustaw. Zgodnie z powołanym przepisem umowa sprzedaży nieruchomości rolnej zbywanej na zasadach określonych w art. 29 ust. 1 i 3 b lub art. 31 ust. 2 ustawy zawiera w szczególności zobowiązania nabywcy nieruchomości do nieprzenoszenia własności nieruchomości nabytej z Zasobu przez okres 15 lat od dnia nabycia nieruchomości oraz do prowadzenia działalności rolniczej na niej w tym okresie, a w przypadku osób fizycznych - do osobistego prowadzenia tej działalności.

${ }^{14}$ P. Wojciechowski, Pojęcie rolnika, w: M. Korzycka (red.), Instytucje prawa rolnego, Warszawa 2019, s. 296 i n. 
w tym produkcji ogrodniczej, sadowniczej i rybnej ${ }^{15}$. Nie jest natomiast jasne, na czym miałoby polegać prowadzenie gospodarstwa rolnego przez nabywcę będącego jednostką organizacyjną (np. osobą prawną), choć formalnie obowiązek ten dotyczy również tej kategorii nabywców. W u.k.u.r. brakuje bowiem wskazówek, co miałoby oznaczać „wykonywanie zawodu rolnika” przez jednostki organizacyjne. Można jedynie stwierdzić, że w ich przypadku prowadzenie gospodarstwa rolnego nie musi mieć charakteru „osobistego”, a to oznaczałoby, że możliwe byłoby np. zawarcie umowy o zarządzanie tym gospodarstwem z osobą trzecią. Akceptacji tego wniosku może stanąć jednak na przeszkodzie równie niejasny zakaz oddawania nabytej nieruchomości osobom trzecim $\mathrm{w}$ posiadanie, wynikający $\mathrm{z}$ art. $2 \mathrm{~b}$ ust. 2 u.k.u.r. Żadna z możliwych interpretacji nie rozwiewa zatem istniejących wątpliwości.

Trudność z precyzyjnym określeniem zakresu obowiązku prowadzenia gospodarstwa rolnego nabiera szczególnego znaczenia w kontekście upowszechnianej przez KOWR restrykcyjnej interpretacji przepisów u.k.u.r., zakładającej, że co do zasady każdy przypadek nabycia nieruchomości rolnej w rozumieniu tej ustawy (o powierzchni co najmniej 30 arów), w wyniku której nabywca staje się właścicielem nieruchomości rolnych o łącznej powierzchni co najmniej 1 ha, generuje po jego stronie „obowiązek prowadzenia gospodarstwa rolnego". Zdaniem KOWR obowiązek ten powstaje również w przypadku, gdy nabywca nieruchomości rolnej jest już właścicielem (użytkownikiem wieczystym) nieruchomości rolnych o łącznej powierzchni co najmniej 1 ha, a nabywana przez niego nieruchomość rolna ma powierzchnię co najmniej 30 arów. Obowiązek prowadzenia gospodarstwa rolnego aktualizuje się również, stosownie do tego kierunku wykładni, gdy nabywca nieruchomości rolnej nie miał dotychczas nic wspólnego z rolnictwem. Istotna jest jedynie okoliczność, że w następstwie nabycia jest - bądź staje się - właścicielem nieruchomości rolnej lub kilku nieruchomości rolnych o łącznej powierzchni co najmniej 1 ha.

Ten kierunek wykładni przechodzi zatem do porządku dziennego nad literalnym brzmieniem art. 2 b u.k.u.r., w którym ustawodawca wyraźnie stwierdził, że obowiązek (osobistego) prowadzenia gospodarstwa rolnego powstaje

${ }^{15} \mathrm{~W}$ tym też kierunku interpretuje związek między pojęciem ,prowadzenie gospodarstwa rolnego" a pojęciem ,prowadzenie działalności rolniczej” A. Suchoń (Pojęcie nieruchomości rolnej, gospodarstwa rolnego i działalności rolniczej w ustawie o ksztaltowaniu ustroju rolnego wybrane kwestie z praktyki notarialnej, „Przegląd Prawa Rolnego” 2019, nr 2, s. 105), choć uściśla, że prowadzenie działalności rolniczej czy gospodarstwa rolnego nie musi łączyć się ze zbytem produktów rolnych (nie musi mieć charakteru działalności gospodarczej). Nie zmienia to jednak faktu, że wytwarzanie produktów rolnych pozostaje nieodłączną cechą ,prowadzenia gospodarstwa rolnego" w rozumieniu przepisów u.k.u.r. 
jedynie w przypadku, gdy nabyta nieruchomość weszła w skład istniejącego już uprzednio gospodarstwa rolnego. Pomija również słuszne spostrzeżenie doktryny, zgodnie z którym ustawowo formułowane kryterium prowadzenia gospodarstwa rolnego ma za zadanie ochronę funkcjonujących gospodarstw rolnych ${ }^{16}$. Jednocześnie podważa trafne tezy przyjęte np. w wyroku Wojewódzkiego Sądu Administracyjnego w Poznaniu z 24 kwietnia 2014 r. ${ }^{17}$, w którym stwierdzono, że samo posiadanie lub własność gospodarstwa rolnego nie mogą być kwalifikowane jako jego prowadzenie, jeżeli nie wiąże się z nimi wykonywanie działalności rolniczej, co obejmuje również podejmowanie decyzji dotyczących prowadzenia działalności rolniczej w tym gospodarstwie ${ }^{18}$.

Praktyczne skutki tego kierunku wykładni nabierają znaczenia w kontekście sankcji za niepodjęcie lub zaprzestanie prowadzenia gospodarstwa rolnego, a w przypadku osoby fizycznej - osobistego prowadzenia gospodarstwa rolnego, w skład którego weszła nabyta nieruchomość rolna w 5-letnim okresie, o którym mowa w art. 2 b ust. 1 u.k.u.r. W świetle art. 9 ust. 3 tego aktu prawnego KOWR może w takiej sytuacji wystąpić do sądu o nabycie własności tej nieruchomości przez KOWR działający na rzecz Skarbu Państwa za zapłatą ceny odpowiadającej jej wartości rynkowej określonej stosownie do przepisów o gospodarce nieruchomościami. Niewykonanie tak niejasno sformułowanego obowiązku, którego treść w rzeczywistości może podlegać swobodnej interpretacji ze strony KOWR (zwłaszcza w odniesieniu do nabywców będących jednostkami organizacyjnymi), naraża zatem nabywcę na utratę nabytej nieruchomości, a przynajmniej na długotrwałe i kosztowne postępowanie sądowe, którego wynik jest trudny do przewidzenia ${ }^{19}$.

${ }^{16}$ A. Bieranowski, Komentarz do art. 166, teza 12, w: M. Fras, M. Habdas (red.), Kodeks cywilny. Komentarz, t. II: Własność i inne prawa rzeczowe (art. 126-352), Warszawa 2018.

17 Wyrok WSA w Poznaniu z 24 kwietnia 2014 r., II SA/Po 93/14.

${ }^{18}$ Za nieporozumienie należy uznać w szczególności akceptację na płaszczyźnie u.k.u.r. poglądu stawiającego znak równości między gospodarstwem rolnym w rozumieniu tej ustawy a nieruchomościami rolnymi o łącznej powierzchni co najmniej 1 ha. Gospodarstwo rolne w rozumieniu u.k.u.r. to przede wszystkim gospodarstwo rolne w rozumieniu art. $55^{3}$ Kodeksu cywilnego, co oznacza, że pojęcie to ma charakter przedmiotowo-funkcjonalny. Gospodarstwo rolne stanowi zatem zorganizowany zespół dóbr, pewną jedność gospodarczą złożoną z określonych elementów. Masa majątkowa jest połączona funkcjonalnie, zmienna ilościowo i rodzajowo. Pomiędzy składnikami gospodarstwa rolnego istnieje więź funkcjonalna o charakterze celowym, ekonomicznym, na tyle silna, że można mówić o nowej jakości, a nie o zbiorze elementów. Funkcjonalne związki między elementami powinny być na tyle mocne, aby masa majątkowa mogła służyć wykonywaniu działalności rolniczej. D. Łobos-Kotowska, Komentarz do art. 553, teza 3, w: M. Fras, M. Habdas (red.), Kodeks cywilny. Komentarz, t. I: Część ogólna (art. 1-125), Warszawa 2018.

${ }_{19} \mathrm{~W}$ tym kontekście należy jednak odnotować zmianę treści art. 9 ust. 3, która nastąpiła 26 czerwca 2019 r. W poprzednim stanie prawnym rola sądu sprowadzona była do zwykłej kon- 


\subsection{Problem ustalenia związku} między obowiązkiem określonym $w$ art. $2 b$ ust. 1 u.k.u.r. a obowiązkiem określonym $w$ art. $2 b$ ust. 2 u.k.u.r.

Zgodnie z restrykcyjnym kierunkiem wykładni nakaz prowadzenia gospodarstwa rolnego, w skład którego weszła nabyta nieruchomość rolna (art. 2 b ust. 1 u.k.u.r.), oraz zakaz zbywania i oddawania w posiadanie innym podmiotom nabytej nieruchomości (art. 2 b ust. 2 u.k.u.r.) stanowią dwa niezależne od siebie obowiązki nabywcy nieruchomości rolnej. W praktyce oznacza to, że gdy przedmiotem nabycia jest nieruchomość rolna położona poza granicami administracyjnymi miasta o powierzchni mniejszej od 1 ha, ale nabywca nie jest właścicielem jakichkolwiek innych nieruchomości rolnych (nie można zatem nawet formalnie założyć, że nabywana nieruchomość wejdzie w skład jego gospodarstwa rolnego), nie znajduje do niego zastosowania obowiązek określony $\mathrm{w}$ art. $2 \mathrm{~b}$ ust. 1 u.k.u.r., ale obowiązuje go zakaz zbywania i oddawania w posiadanie innym podmiotom, wynikający $\mathrm{z}$ art. 2 b ust. 2 u.k.u.r.

Wykładnia ta pozostaje w sprzeczności z poruszaną w literaturze koniecznością łącznego uwzględniania obu wymienionych obowiązków, jako ściśle ze sobą powiązanych, zarówno z uwagi na systematykę art. 2b u.k.u.r., jak i podstawowe założenia tego aktu prawnego ${ }^{20}$.

\subsection{Obowiązki wynikające $z$ art. $2 b$ u.k.u.r. a obrót rodzinny nieruchomościami rolnymi}

Zgodnie z restrykcyjnym kierunkiem wykładni norm prawnych wynikających $\mathrm{z}$ art. $2 \mathrm{~b}$ u.k.u.r. do osób bliskich zbywcy znajduje zastosowanie znowelizowana w 2019 r. treść art. 2 b ust. 4 pkt 1 lit a u.k.u.r., co oznacza, że możliwość dalszego rozporządzania nabytą przez nich nieruchomością bez zgody KOWR zostaje ograniczona do sytuacji określonych $w$ art. $2 b$ ust. $4 \mathrm{w}$ jego aktualnym brzmieniu. W konsekwencji bez zgody KOWR określonej w art. 2 b ust. 3 u.k.u.r. osoby te mogą zbyć nabytą nieruchomość przed upływem 5-letniego terminu jedynie np. na rzecz osoby bliskiej, jednostki samorządu terytorialnego, Skarbu Państwa lub działającego na jego rzecz KOWR, w wyniku wykonania umowy z następcą, jeżeli następca ten

firmacji wniosku KOWR o nabycie własności nieruchomości rolnej. Obecna redakcja tego przepisu zdaje się jednak przyznawać sądowi pewne kompetencje kontrolne w zakresie rzetelności wniosku KOWR.

${ }^{20}$ Szerzej na ten temat: P.A. Blajer, Umowa sprzedaży nieruchomości rolnej ..., s. 135. 
w chwili nabycia będzie rolnikiem indywidualnym, i na rzecz pozostałych podmiotów, określonych $\mathrm{w}$ art. $2 \mathrm{~b}$ ust. 4 u.k.u.r. w jego aktualnym brzmieniu. We wspólnym stanowisku Ministerstwa Rolnictwa i Rozwoju Wsi, Krajowego Ośrodka Wsparcia Rolnictwa oraz Krajowej Rady Notarialnej z 27 lutego 2020 r. w sprawie stosowania w praktyce ustawy o kształtowaniu ustroju rolnego wskazano jedynie, że nowa treść art. 2 b ust. 4 nie stanowi podstawy „wstecznego" nałożenia obowiązków oraz obostrzeń na osoby, które nabyły nieruchomości rolne bez obciążenia obostrzeniami z art. $2 b$ ustawy (np. wszelkich nabywców nieruchomości sprzed 30 kwietnia 2016 r. lub podmiotów, które nabyły nieruchomości rolne przed wejściem w życie noweli, tj. pomiędzy 30 kwietnia 2016 r. a 26 czerwca 2019 r.) na zasadach podlegających dotychczasowemu brzmieniu art. 2 b ust. 4 u.k.u.r. A contario, w przypadku nabycia nieruchomości rolnej po 26 czerwca 2019 r. przez osobę bliską w pełnym zakresie znajdują do niej zastosowanie obowiązki określone w art. $2 \mathrm{~b}$ ust. 1 i 2.

Wykładni tej słusznie zarzucono sprzeczność z literalnym brzmieniem art. 2 b ust. 4 pkt 1 lit a u.k.u.r. ${ }^{21}$ Ponadto zauważono, że jej słabą stroną jest eksponowanie wyłącznie obowiązku $\mathrm{z}$ art. 2 b ust. 2 u.k.u.r. (zakazu zbywania lub oddawania w posiadanie osobie trzeciej) kosztem obowiązku określonego w ust. 1 tego artykułu (nakazu prowadzenia gospodarstwa rolnego, w skład którego weszła nabyta nieruchomość $)^{22}$. Jak się wydaje, w kontrze do tego ostatniego argumentu KOWR zajął stanowisko, że osoba bliska, która nabyła nieruchomość rolną po 26 czerwca 2019 r., ma również obowiązek prowadzenia gospodarstwa rolnego, w skład którego weszła nabyta nieruchomość (art. 2 b ust. 1 u.k.u.r. $)^{23}$. Ze względu na wcześniejsze uwagi na temat niejasnej treści obowiązku prowadzenia gospodarstwa rolnego należy stwierdzić, że akceptacja tego kierunku wykładni prowadzi do istotnych skutków praktycznych. Każde bowiem nabycie (np. w drodze darowizny) przez osobę

${ }^{21}$ Szerzej na ten temat: P. Bender, Podstawowe problemy stosowania znowelizowanej ustawy o ksztaltowaniu ustroju rolnego (cz. II), „Rejent” 2019, nr 12, s. 61 i n.

${ }_{22}$ P.A. Blajer, Umowa sprzedaży nieruchomości rolnej ..., s. 126-127.

${ }^{23}$ Zostało ono jednoznacznie sformułowane podczas obrad poznańskiej konferencji „Obrót nieruchomościami rolnymi - teoria i praktyka". Wyrażony tam został także pogląd, że zasada ta obowiązuje w odniesieniu do pozostałych podmiotów wymienionych w art. $2 \mathrm{~b}$ ust. 4 pkt 1), tj. np. jednostki samorządu terytorialnego, Skarbu Państwa lub działającego na jego rzecz KOWR (sic!) albo też spółki kapitałowej lub grupy kapitałowej, o których mowa w art. 1 ust. 1 ustawy z 18 marca 2010 r. o szczególnych uprawnieniach ministra właściwego do spraw energii oraz ich wykonywaniu w niektórych spółkach kapitałowych lub grupach kapitałowych prowadzących działalność w sektorach energii elektrycznej, ropy naftowej oraz paliw gazowych w przypadku nabycia nieruchomości rolnej na cele związane z budową, modernizacją lub rozbudową mienia określonego w art. 1 ust. 2 tej ustawy. 
bliską nieruchomości rolnej o powierzchni co najmniej 30 arów, w przypadku gdy osoba ta jest już właścicielem (lub użytkownikiem wieczystym) nieruchomości rolnych o powierzchni co najmniej 1 ha albo jeżeli w wyniku nabycia staje się właścicielem nieruchomości o takiej powierzchni, może skutkować zastosowaniem sankcji z art. 9 ust. 3 u.k.u.r., gdy KOWR uzna, że nabywca nie czyni zadość obowiązkowi wynikającemu z art. 2b ust. 1 u.k.u.r. Ujmując problem bardziej obrazowo, można powiedzieć, że podział gospodarstwa dokonany przez rolnika pomiędzy dzieci w wyżej opisanych warunkach może doprowadzić do przejęcia tego gospodarstwa przez KOWR działający na rzecz Skarbu Państwa, a tym samym do utraty rodzinnego majątku ${ }^{24}$. Warto więc podkreślić, że podstawę prawną takich konsekwencji stanowią przepisy ustawy, której głównym celem jest wzmocnienie ochrony i rozwoju gospodarstw rodzinnych, stanowiących w myśl Konstytucji RP podstawę ustroju rolnego Rzeczypospolitej Polskiej.

\subsection{Obowiązki nabywcy nieruchomości rolnej wynikające $z$ art. $2 b$ u.k.u.r. w kontekście sytuacji dzierżawców nieruchomości rolnych}

Jednym z szerzej dyskutowanych w literaturze problemów związanych ze stosowaniem ustawy o kształtowaniu ustroju rolnego po nowelizacji z 2016 r. jest jej wpływ na pozycję prawną dzierżawców nieruchomości rolnych, jako podmiotów efektywnie prowadzących działalność rolniczą na nieruchomościach będących przedmiotem obrotu własnościowego ${ }^{25}$. Zagadnienie to nabiera znaczenia w kontekście celów u.k.u.r., jakimi są

${ }^{24} \mathrm{~W}$ praktyce problem ten może powstać przede wszystkim w sytuacji, gdyby nabywca będący osobą bliską zbywcy wystąpił do dyrektora generalnego KOWR w trybie art. 2b ust. 3 o zgodę na zbycie nabytej nieruchomości rolnej przed upływem 5 lat od dnia przeniesienia własności tej nieruchomości. W takiej sytuacji KOWR może formalnie w trybie art. 8a u.k.u.r. przeprowadzić kontrolę spełnienia warunków, o których mowa w art. $2 \mathrm{~b}$ ust. 1 , a następnie wystąpić do sądu w trybie art. 3 ust. 3 u.k.u.r. o nabycie własności tej nieruchomości przez KOWR działający na rzecz Skarbu Państwa, za zapłatą ceny odpowiadającej jej wartości rynkowej określonej stosownie do przepisów o gospodarce nieruchomościami. Jak można założyć, ze względu na oczywiste protesty i kontrowersje, jakie tego typu działania mogłyby wywołać w przestrzeni publicznej, uciekanie się do nich przez KOWR nie będzie częste. Nie należy jednak zapominać, że przy akceptacji dominującej obecnie wykładni przepisów art. 2 b u.k.u.r. opisany instrument pozostaje formalnie do dyspozycji KOWR; kwestią otwartą jest zaś częstotliwość i przesłanki jego aktywacji.

${ }^{25} \mathrm{P}$. Wojciechowski, Wybrane aspekty ograniczenia obrotu nieruchomościami rolnymi w prawie polskim $w$ kontekście unijnej zasady swobody przepływu kapitatu, „Przegląd Prawa Rolnego" 2020, nr 2, s. 47-48; A. Suchoń, Pojęcie nieruchomości rolnej..., s. 106-107. 
m.in. „zapewnienie właściwego zagospodarowania ziemi rolnej w Rzeczypospolitej Polskiej”, ,,poprawa struktury obszarowej gospodarstw rolnych” czy „zapewnienie prowadzenia działalności rolniczej w gospodarstwach rolnych przez osoby o odpowiednich kwalifikacjach" (preambuła, art. 1 pkt 1) i 3) u.k.u.r.).

Zarysowany wyżej problem w rzeczywistości jest złożony i wieloaspektowy. Można go odnieść zarówno do dzierżaw przyszłych (tzn. zawieranych przez nabywcę nieruchomości rolnej w ramach 5-letniego okresu po jej nabyciu), jak i do dzierżaw istniejących w chwili nabycia nieruchomości rolnej.

W pierwszym przypadku za naruszające art. 2 b ust. 2 u.k.u.r. należałoby uznać zadysponowanie nieruchomością skutkujące oddaniem w posiadanie w drodze dzierżawy, jeśli wiąże się z odstąpieniem przez właściciela władztwa nad jej częścią rolno-produkcyjną ${ }^{26}$. Problem sprowadza się zatem do konieczności uzyskania zgody dyrektora generalnego KOWR na wydzierżawienie ,rolno-produkcyjnej” części nieruchomości rolnej przed upływem okresu 5 lat od dnia przeniesienia jej własności. Powyższe stanowisko jest oczywiście słuszne, choć należy zwrócić uwagę na możliwe praktyczne problemy z ustaleniem części „rolno-produkcyjnej” danej nieruchomości w konkretnym przypadku, co stanowi zachętę do „ostrożnościowego”, tj. maksymalnie szerokiego, interpretowania tego obowiązku ${ }^{27}$. W tym kontekście można też zauważyć, że określone w art. 2 b ust. 3 u.k.u.r. przesłanki wyrażenia przez dyrektora generalnego KOWR zgody na zbycie nieruchomości rolnej ograniczone są wyłącznie do ,przypadków uzasadnionych ważnym interesem nabywcy nieruchomości rolnej lub interesem publicznym". Przesłanki te nie uwzględniają oddania nieruchomości rolnej w posiadanie osobie trzeciej, która włączy ją w prowadzone przez siebie gospodarstwo rolne. Innymi słowy, wola i potrzeba potencjalnego dzierżawcy powiększenia efektywnie funkcjonującego gospodarstwa rolnego nie może stanowić samodzielnej przesłanki wyrażenia zgody na oddanie mu nieruchomości w dzierżawę ${ }^{28}$.

W kontekście dzierżaw zawieranych w ramach 5-letniego okresu następującego po nabyciu nieruchomości rolnej należy zwrócić uwagę na sankcję braku uzyskania zgody dyrektora generalnego KOWR na dokonanie takiej czynności. Zgodnie z art. 9 ust. 1 pkt 2 u.k.u.r. jest nią nieważność czynności

${ }^{26}$ P. Bender, Podstawowe problemy..., s. 50.

${ }^{27}$ Warto zwrócić uwagę, że obowiązek uzyskania zgody na oddanie nieruchomości rolnej w dzierżawę zgodnie z art. 2 b ust. 2 u.k.u.r. nie uwzględnia żadnych kryteriów obszarowych. Wydzierżawienie nieznacznego areału gruntów rolnych, np. na rzecz sąsiada, również implikuje konieczność uzyskania zgody dyrektora generalnego KOWR.

${ }_{28}$ P. Wojciechowski, Wybrane aspekty..., s. 49. 
prawnej $^{29}$. Sankcja ta jest bardzo dotkliwa, głównie ze względu na skromne wymogi formalne wobec umowy dzierżawy, określane przez Kodeks cywilny. Udział notariuszy w tego typu czynnościach ogranicza się co najwyżej do poświadczenia podpisów na dokumencie obejmującym umowę dzierżawy lub nadania mu daty pewnej. W konsekwencji strony dzierżawy są z reguły pozbawione dostępu do profesjonalnej pomocy prawnej, dzięki której uświadomiłyby sobie doniosłość sankcji za nieprzestrzeganie zakazu oddawania nieruchomości w posiadanie wynikającego $\mathrm{z}$ art. $2 \mathrm{~b}$ ust. 2 u.k.u.r. Problem ten staje się tym poważniejszy, że sankcja wynikająca z art. 9 ust. 1 pkt 2 u.k.u.r. (nieważność czynności prawnej) nie stanowi jedynego zagrożenia dla stron tej czynności. Wielokrotnie podkreślana niejasna treść obowiązku (osobistego) prowadzenia gospodarstwa rolnego może prowadzić do wniosku, że oddanie w posiadanie nieruchomości na podstawie bezwzględnie nieważnej umowy dzierżawy uniemożliwia jednocześnie wydzierżawiającemu zadośćuczynienie obowiązkowi wynikającemu $\mathrm{z}$ art. $2 \mathrm{~b}$ ust. 1 u.k.u.r. W takiej sytuacji - zgodnie z wyraźnym brzmieniem art. 9 ust. 3 pkt 1 lit b) u.k.u.r. KOWR może wystąpić do sądu o nabycie własności tej nieruchomości przez KOWR działający na rzecz Skarbu Państwa. W konsekwencji naruszenie (nawet nieświadome) przez właściciela nieruchomości zakazu oddawania nieruchomości w dzierżawę w ramach 5-letniego okresu następującego po jej nabyciu może doprowadzić do jego wywłaszczenia.

Dla pozycji prawnej dzierżawców nieruchomości rolnych jeszcze poważniejsze konsekwencje może mieć akceptacja restrykcyjnej wykładni przepisów art. $2 \mathrm{~b}$ u.k.u.r. w odniesieniu do dzierżaw istniejących w chwili nabycia nieruchomości rolnej. Zgodnie z upowszechnianym przez KOWR kierunkiem interpretacji okoliczność, że nieruchomość w momencie przeniesienia jej własności znajduje się w dzierżawie, uniemożliwia nabywcy zadośćuczynienie obowiązkowi (osobistego) prowadzenia gospodarstwa rolnego. Utartym sposobem postępowania KOWR w tym przypadku jest np. uzależnianie wydania zgody na nabycie nieruchomości rolnej w trybie art. 2a ust. 4 u.k.u.r. (w przypadkach, gdy jest ona wymagana) od uprzedniego rozwiązania umowy dzierżawy. W praktyce jednak notariusze odmawiają udokumentowania czynności prawnej prowadzącej do przeniesienia własności na rzecz rolnika indywidualnego (a więc gdy zgoda KOWR w trybie art. 2a ust. 4 nie jest wymagana), jeżeli nieruchomość ta znajduje się, nawet częściowo, w dzierżawie. Przyczynę odmowy stanowi argument o niemożności spełnienia przez nabywcę obowiązku (osobistego) prowadzenia go-

${ }^{29}$ Tak zapewne należy rozumieć niefortunne określenie „nieważność oddania w posiadanie nieruchomości rolnej”. 
spodarstwa rolnego. Ta $\mathrm{z}$ gruntu błędna praktyka wynika $\mathrm{z}$ upowszechniania opisanej wyżej restrykcyjnej interpretacji przepisów art. 2b u.k.u.r. ${ }^{30}$

Przedstawione okoliczności pozwalają uznać, że dominujący obecnie kierunek wykładni art. 2 b u.k.u.r. stanowi istotne zagrożenie dla interesów zarówno wydzierżawiających, jak i dzierżawców nieruchomości rolnych. Dla właściciela nieruchomości rolnej jej wydzierżawienie oznacza obecnie faktyczną niemożność rozporządzenia nieruchomością bez współdziałania ze strony dzierżawcy. Nieruchomość rolna znajdująca się w dzierżawie może być bowiem zbyta na rzecz dzierżawcy albo innego podmiotu, o ile - w tym ostatnim wypadku - dzierżawca wyrazi zgodę na rozwiązanie umowy dzierżawy. Tylko bowiem w następstwie wygaśnięcia stosunku dzierżawy nabywca takiej nieruchomości będzie mógł spełnić obowiązek (osobistego) prowadzenia gospodarstwa rolnego ${ }^{31}$. To rozwiązanie tylko pozornie wzmacnia pozycję dzierżawców. Trudno bowiem nie dojść do wniosku, że w rzeczywistości skutecznie zniechęca ono właścicieli nieruchomości rolnych do ich wydzierżawiania. A to może prowadzić do spadku popularności prowadzenia działalności rolniczej w oparciu o stosunek dzierżawy $^{32}$.

Na podstawie tych obserwacji można stwierdzić, że pozbawienie - w wyniku akceptacji dominującego kierunku wykładni - normatywnego znaczenia wynikającej z art. 3 ust. 1 u.k.u.r. instytucji pierwokupu dzierżawcy wydaje się już okolicznością o niewielkim ciężarze gatunkowym ${ }^{33}$.

${ }^{30}$ Odmowa dokonania czynności jest w tym wypadku bezzasadna, zważywszy na to, że czynność jest ważna i skuteczna, nie wchodzi bowiem w grę sankcja przewidziana za oddanie nieruchomości rolnej w posiadanie osobie trzeciej bez zgody KOWR, skoro nieruchomość znajduje się już w posiadaniu osoby trzeciej. Stosownie jednak do założeń wykładni restrykcyjnej KOWR może wówczas skorzystać z uprawnienia przysługującego mu na podstawie art. 9 ust. 3 u.k.u.r. wobec „niepodjęcia” przez nabywcę prowadzenia gospodarstwa rolnego.

${ }^{31}$ Zgodnie z restrykcyjnym kierunkiem wykładni sytuacja taka może mieć miejsce wyłącznie w przypadku, gdy w następstwie nabycia nieruchomości rolnej nabywca staje się lub już jest właścicielem gospodarstwa rolnego w rozumieniu u.k.u.r. Tylko wtedy bowiem powstaje po jego stronie obowiązek prowadzenia gospodarstwa. Z drugiej strony, zgodnie z tym kierunkiem interpretacji powyższe konsekwencje prawne należy odnieść również do obrotu rodzinnego, przede wszystkim do sytuacji, gdy nabywcą (np. na podstawie umowy darowizny) jest osoba bliska zbywcy.

32 Teza ta może wydawać się nieco paradoksalna w związku ze wzrostem popularności umowy dzierżawy w stosunkach wiejskich z uwagi na istotne ograniczenia obrotu własnościowego wprowadzone w 2016 r. Można jednak przypuszczać, że strony tych umów nie są do końca świadome konsekwencji prawnych ich zawarcia, w kontekście zaskakujących wniosków płynących $\mathrm{z}$ akceptacji dominującej wykładni przepisów art. $2 \mathrm{~b}$ u.k.u.r.

${ }_{33} \mathrm{~W}$ literaturze zaproponowane zostały odmienne sposoby interpretacji obowiązków nabywcy nieruchomości rolnej wynikających z art. $2 \mathrm{~b}$ u.k.u.r. w przypadku, gdy znajduje się ona w dzierżawie. Por. A. Suchoń, Pojęcie nieruchomości rolnej..., s. 107. Praktyka obrotu wskazuje jednak, że mają one jedynie walor interesującej propozycji doktrynalnej. 


\subsection{Następcza zmiana przeznaczenia nabytej nieruchomości a obowiązki jej nabywcy wynikające $z$ art. 2 b u.k.u.r.}

Jednym z najbardziej kontrowersyjnych założeń upowszechnianego przez KOWR restrykcyjnego kierunku wykładni art. 2 b u.k.u.r. jest teza o utrzymywaniu się obu wynikających z niego obowiązków w przypadku utraty przez nieruchomość jej rolnego charakteru w trakcie 5-letniego okresu następującego po nabyciu. Innymi słowy, pomimo następczego wejścia w życie miejscowego planu zagospodarowania przestrzennego, w którym nieruchomość została przeznaczona na cele inne niż rolne, nabywcy nieruchomości rolnej nadal dotyczy generalny nakaz prowadzenia gospodarstwa rolnego, w skład którego weszła nabyta nieruchomość, jak również zakaz zbywania tej nieruchomości oraz oddawania jej w posiadanie osobom trzecim.

W tym względzie propagowana w praktyce obrotu wykładnia pozostaje w sprzeczności z zasadniczo jednomyślnymi poglądami wyrażanymi na ten temat $\mathrm{w}$ literaturze ${ }^{34}$. Prezentowane $\mathrm{w}$ niej argumenty są powszechnie znane; wystarczy więc tylko wspomnieć, że biorą one pod uwagę względy natury celowościowej, systemowej, ale przede wszystkim literalne brzmienie tekstu u.k.u.r. Niestety, są one konsekwentnie odrzucane przez KOWR, co prowadzi do paradoksalnego wniosku, że obciążony obowiązkami wynikającymi z art. 2b właściciel nieruchomości, której przeznaczenie zmieniono w miejscowym planie zagospodarowania przestrzennego na cele inne niż rolne, nadal ma obowiązek prowadzenia działalności wytwórczej w rolnictwie, w ramach gospodarstwa rolnego, w skład którego weszła nabyta nieruchomość, pod groźbą utraty jej własności (art. 9 ust. 3 u.k.u.r.) Koncepcję tę trudno pogodzić z systemowymi regulacjami ustawy z 27 marca $2003 \mathrm{r}$. o planowaniu i zagospodarowaniu przestrzennym ${ }^{35}$ lub ustawy z 3 lutego 1995 r. o ochronie gruntów rolnych i leśnych ${ }^{36}$.

Restrykcyjny kierunek wykładni przepisów art. $2 \mathrm{~b}$ u.k.u.r. nie ogranicza się wyłącznie do utrzymania w mocy obowiązków nabywcy nieruchomości rolnej pomimo utraty przez nieruchomość jej rolnego charakteru, w ramach 5-letniego okresu następującego po nabyciu. Zmierza on również do zacho-

${ }^{34}$ A. Michnik, Obowiązi nabywcy nieruchomości rolnej wynikajace z ustawy z dnia 11 kwietnia 2003 r. o ksztaltowaniu ustroju rolnego, „Krakowski Przegląd Notarialny” 2017, nr 1, s. 105; P. Bender, Podstawowe problemy..., s. 84; A. Bieranowski. Uwagi ..., s. 114; P. Blajer, Umowa sprzedaży..., s. 122.

35 Ustawa z 27 marca 2003 r. o planowaniu i zagospodarowaniu przestrzennym (t.j. Dz. U. z 2020 r., poz. 293 ze zm.).

${ }^{36}$ Ustawa z 3 lutego 1995 r. o ochronie gruntów rolnych i leśnych (t.j. Dz. U. z 2017 r., poz. 1161 ze zm.). 
wania ograniczeń wynikających z art. 2b u.k.u.r. (w szczególności zakazu zbywania lub oddawania $\mathrm{w}$ posiadanie osobom trzecim) $\mathrm{w}$ odniesieniu do nieruchomości wydzielonych z nabytej nieruchomości rolnej, o powierzchni mniejszej niż 30 arów, a więc takich, do których zgodnie z brzmieniem art. 1a pkt 1 lit b) u.k.u.r. przepisy tej ustawy nie mają zastosowania. Uzasadnienia tej tezy poszukuje się w zasadniczo słusznym założeniu, że czynności o charakterze ściśle technicznym (np. podział geodezyjny lub wieczystoksięgowy nieruchomości) nie powinny prowadzić do zanegowania obowiązku (osobistego) prowadzenia gospodarstwa rolnego wynikającego $\mathrm{z}$ art. $2 \mathrm{~b}$ ust. 1 u.k.u.r. ${ }^{37} \mathrm{~W}$ literaturze jednak można znaleźć dobrze uargumentowaną i przekonującą krytykę tego poglądu, odwołującą się przede wszystkim do literalnego brzmienia ustawy ${ }^{38}$.

Niemal jednomyślne odrzucenie w doktrynie obu zarysowanych aspektów restrykcyjnej wykładni norm prawnych wynikających z art. 2b u.k.u.r. nie zmienia faktu, że dominują one w praktyce, głównie ze względu na konsekwentną postawę KOWR, wymuszającą - z powodu braku stosownego orzecznictwa - ich akceptację wśród pozostałych uczestników obrotu ${ }^{39}$.

W związku z tym warto przedstawić jeszcze kilka obserwacji o charakterze ogólnym. Teza o utrzymaniu obowiązków nabywcy nieruchomości rolnej wynikających z art. $2 \mathrm{~b}$ u.k.u.r. w przypadku utraty przez nieruchomość charakteru rolnego (co ma znaczenie zwłaszcza w odniesieniu do nakazu prowadzenia gospodarstwa rolnego) lub jej podziału skutkującego wydzieleniem nieruchomości o powierzchni poniżej 30 arów (co ma znaczenie w odniesieniu do zakazu jej zbywania lub oddawania w posiadanie osobie trzeciej) jest nie tylko sprzeczna z literalnym brzmieniem u.k.u.r. oraz celami, które ten akt prawny ma realizować, ale także stawia pod znakiem zapyta-

${ }^{37}$ Por. P. Blajer, Umowa sprzedaży..., s. 123-124. Autor, uznając argumenty przemawiające na korzyść tego stanowiska, zauważa jednak, że samo zaistnienie zdarzeń warunkujących podział geodezyjny nieruchomości rolnych na działki o powierzchni mniejszej niż 30 arów, takich jak wejście w życie miejscowego planu zagospodarowania przestrzennego, a w szczególności uostatecznienie się decyzji o warunkach zabudowy i zagospodarowania terenu, powinno oznaczać ustanie obowiązków nabywcy wynikających $\mathrm{z}$ art. $2 \mathrm{~b}$ u.k.u.r.

${ }^{38}$ Por. J. Bieluk, Ustawa o ksztattowaniu ustroju rolnego. Komentarz, Warszawa 2019, s. 188; A. Bieranowski, Uwagi..., s. 116; P. Bender, Podstawowe problemy..., s. 93-95.

${ }^{39}$ Głosy płynące z praktyki wskazują na przyjęty przez KOWR modus operandi, polegający np. na kierowaniu do notariuszy pism wzywających do „rozwiązania” lub ,unieważnienia” (sic!) bezwzględnie nieważnych zdaniem KOWR umów zawartych z naruszeniem zakazów i nakazów wynikających z art. 2 b u.k.u.r. Stosowna korespondencja w tym względzie, mająca upowszechniać przyjmowany przez KOWR restrykcyjny kierunek wykładni przepisów u.k.u.r., kierowana jest również do sądów wieczystoksięgowych. Podstawy prawne takich działań KOWR, jak również merytoryczna zawartość powołanych pism, których celem jest zapewne wywołanie zgodnego z oczekiwaniami KOWR efektu psychologicznego, zasługują jednak na odrębną analizę. 
nia bezpieczeństwo obrotu prawnego w Polsce. W rzeczywistości bowiem zmusza ona uczestników obrotu do dokonywania niezwykle szczegółowych ustaleń w zakresie stanu prawnego i faktycznego danej nieruchomości gruntowej. W praktyce określenie reżimu prawnego, któremu dana nieruchomość podlega, powinno de lege lata rozpoczynać się nie tyle od wskazania jej aktualnego przeznaczenia $\mathrm{w}$ miejscowym planie zagospodarowania przestrzennego lub oznaczenia jej w ewidencji gruntów i budynków albo ustalenia jej powierzchni, ile od wskazania daty, w której nieruchomości ta została nabyta. Jeśli od daty tej nie minęło 5 lat, to powinna nastąpić seria dalszych ustaleń zmierzających do określenia, czy jej nabywca jest obarczony obowiązkami wynikającymi z art. 2 b u.k.u.r. Ustalenia te powinny objąć takie okoliczności, jak:

- datę wejścia w życie miejscowego planu zagospodarowania przestrzennego lub jego zmian (albo utraty przez plan mocy obowiązującej z datą wsteczną - ex $\operatorname{tunc}^{40}$ ),

- ewentualne zmiany oznaczenia nieruchomości w ewidencji gruntów i budynków,

- ewentualne wydanie dla danej nieruchomości ostatecznej decyzji o warunkach zabudowy i zagospodarowania terenu,

- historię podziałów nieruchomości zarówno w aspekcie geodezyjnym, jak i wieczystoksięgowym,

- szczegółowe badanie podstawy nabycia, przy czym o ile akt notarialny dokumentujący czynność prawną z reguły zawiera w tym względzie określone wskazówki (do których wszelako nie można podchodzić bezkrytycznie), o tyle taka sytuacja nie będzie miała miejsca w odniesieniu np. do orzeczeń sądowych lub rozstrzygnięć organów administracji publicznej, stanowiących w konkretnym przypadku podstawę nabycia nieruchomości.

Ustalenie takich okoliczności może okazać się w wielu sytuacjach trudne, a nawet niemożliwe. Istnieje też ryzyko zwykłego przeoczenia jednej z wymienionych okoliczności, z których każda może być rozstrzygająca dla stwierdzenia, czy aktualny właściciel nieruchomości jest obarczony nakazami i zakazami wynikającymi $\mathrm{z}$ art. $2 \mathrm{~b}$ u.k.u.r.

Ciężar dokonania takich ustaleń spoczywa głównie na notariuszach, w związku z ich obowiązkiem odmowy dokonania czynności sprzecznej z prawem (art. 81 Prawa o notariacie ${ }^{41}$ ), ale do pewnego stopnia także na sądach prowadzących księgi wieczyste, $\mathrm{z}$ uwagi na stosunkowo szeroko zakreśloną w prawie polskim kognicję tych sądów, obejmującą także waż-

40 Jest to np. następstwem stwierdzenia nieważności planu przez organ nadzoru w trybie art. 91 ustawy z 8 marca 1990 r. o samorządzie gminnym (t.j. Dz. U. z 2020 r., poz. 713).

${ }^{41}$ Ustawa z 14 lutego 1991 r. Prawo o notariacie (t.j. Dz. U. z 2020 r., poz. 1192). 
ność czynności prawnej mającej stanowić podstawę wpisu (art. $626^{8}$ k.p.c.). $\mathrm{W}$ tym kontekście dominującą $\mathrm{w}$ praktyce obrotu restrykcyjną wykładnię norm prawnych wynikających $\mathrm{z}$ art. $2 \mathrm{~b}$ u.k.u.r. należy postrzegać jako istotne zagrożenie zarówno dla instytucji notariatu par excellance, jak i dla polskiego systemu wieczystoksięgowego ${ }^{42}$, $\mathrm{tj}$. dwóch filarów obrotu nieruchomościami w Polsce. Ryzyko niewłaściwych ustaleń dotyczących zarówno charakteru nieruchomości, jak i okoliczności związanych z aktualizacją obowiązków wynikających z art. 2b u.k.u.r. jest na tyle duże, że $\mathrm{w}$ wielu przypadkach notariusze nie są w stanie zagwarantować stronom dokumentowanych czynności odpowiedniego poziomu bezpieczeństwa ${ }^{43}$. Sytuacja ta prowadzi do spadku zaufania społecznego do notariuszy, dla których zadanie zapewnienia bezpieczeństwa obrotu prawnego i jego zgodności z obowiązującym prawem przestaje być wykonalne ${ }^{44}$. W konsekwencji regulacje u.k.u.r., w tym te wynikające $\mathrm{z}$ art. $2 \mathrm{~b}$, prowadzą do przewartościowania modelu obrotu nieruchomościami (nie tylko rolnymi) funkcjonującego dotychczas w Polsce i poszukiwania alternatywnych sposobów zabezpieczenia stron transakcji ${ }^{45}$.

${ }^{42}$ Aktualne regulacje u.k.u.r. ograniczają również zaufanie do ksiąg wieczystych; zwiększa się bowiem ryzyko wystąpienia niezgodności między treścią księgi wieczystej a rzeczywistym stanem prawnym na skutek ujawnienia w księgach ,nieważnych” (przynajmniej zgodnie z dominującym kierunkiem wykładni przepisów u.k.u.r.) przypadków nabycia nieruchomości (np. uchybienia zakazowi zbywania przewidzianemu w art. 2 b ust. 2 u.k.u.r.).

${ }^{43}$ Sytuacja ta skutkuje sygnalizowaną w obrocie powszechnością nieformalnych odmów dokonania czynności notarialnych w sprawach nieruchomości o niejasnym statusie. Odmowy takie, często zresztą nieuzasadnione, wynikają z obawy przed udokumentowaniem nieważnych czynności prawnych. A to przynosi efekt „mrożący”, a nawet „paraliżujący” obrót nieruchomościami.

${ }^{44} \mathrm{Z}$ praktyki obrotu wynika, że coraz częściej podejmowane są próby kwestionowania ważności nabycia nieruchomości z uwagi na nieprecyzyjne regulacje u.k.u.r., w tym zawarte w art. 2b. Podejmuje je nie tylko KOWR, działający formalnie w interesie publicznym, ale także różnego rodzaju podmioty aktywne na rynku nieruchomości, których interesy nie zawsze zasługują na ochronę. Paradoksalnie więc ustawa mająca przeciwdziałać spekulacji nieruchomościami sama może stać się źródłem takich spekulacji.

${ }^{45} \mathrm{Na}$ odrębne opracowanie zasługuje kwestia związków między systemem obrotu ziemią rolną w Polsce a aksjologicznymi i celowościowymi podstawami funkcjonowania notariatu. Warto tylko wspomnieć, że akty prawne tworzące zręby tego systemu, w tym u.k.u.r., stanowią od lat pole doświadczalne dla różnych przypadkowych i nieprzemyślanych koncepcji, wdrażanych w oderwaniu od fundamentalnych zasad obrotu nieruchomościami w Polsce. Przykładem takich regulacji jest instytucja pierwokupu sąsiedzkiego, przewidziana w art. 9 ust. 2 ustawy z 5 sierpnia 2015 r. o kształtowaniu ustroju rolnego (Dz. U. poz. 1433). Szerzej: P. Blajer, Sasiedzkie prawo pierwokupu a struktura gruntowa polskich gospodarstw rolnych - panaceum czy pandemonium?, „Przegląd Prawa Rolnego” 2015, nr 2, s. 45 i n. Taką regulację stanowi też art. 2 b u.k.u.r., przynajmniej przy akceptacji dominującego obecnie w obrocie kierunku wykładni wynikających z niego przepisów. 


\section{Kwestia zgodności z prawem Unii Europejskiej obowiązków nabywcy nieruchomości rolnej wynikających z art. $2 b$ u.k.u.r.}

Problem zgodności z prawem Unii Europejskiej polskich regulacji z zakresu obrotu nieruchomościami rolnymi, w tym rozwiązań przyjętych w u.k.u.r., jest przedmiotem wielu wypowiedzi doktryny ${ }^{46}$. W niniejszym artykule rozważania zostaną ograniczone do kwestii zgodności z prawem unijnym obowiązków nabywcy nieruchomości rolnej określonych w art. 2b u.k.u.r. w świetle wyżej opisanego, dominującego w praktyce obrotu, restrykcyjnego kierunku jego wykładni.

Podstawę dalszych analiz będzie stanowić szeroko analizowane orzecznictwo Trybunału Sprawiedliwości Unii Europejskiej (TSUE) dotyczące legalności krajowych ograniczeń w nabywaniu nieruchomości rolnych w kontekście zasady niedyskryminacji, zasady swobody działalności gospodarczej oraz swobody przepływu kapitału ${ }^{47}$, jak również dwa akty prawne należące do tzw. miękkiego prawa Unii Europejskiej, tj. rezolucja Parlamentu Europejskiego z 27 kwietnia 2017 r. w sprawie aktualnego stanu koncentracji gruntów rolnych w UE: jak ułatwić rolnikom dostęp do gruntów? ${ }^{48}$ oraz komunikat wyjaśniający Komisji w sprawie nabywania gruntów rolnych i prawa Unii Europejskiej ${ }^{49}$. Wnioski wynikające z analizy tych źródeł można streścić następująco: krajowe ograniczenia w obrocie nieruchomościami rolnymi stanowią jednocześnie ogranicze-

${ }^{46}$ M. Mataczyński, W kwestii zgodności ustawy z 11 kwietnia 2003 r. o ksztaltowaniu ustroju rolnego z prawem europejskim w świetle orzecznictwa Europejskiego Trybunału Sprawiedliwości, „Rejent” 2004, nr 5, s. 73 i n.; P. Czechowski, Obrót nieruchomościami rolnymi w świetle europejskiego soft law, „Studia Iuridica Agraria” 2018, t. XVI, s. 29 i n.; P. Czechowski, A. Niewiadomski, Mechanizmy prawne ochrony rolnego charakteru nieruchomości w świetle rezolucji Parlamentu Europejskiego z dnia 27 kwietnia 2017 r. w sprawie aktualnego stanu koncentracji gruntów rolnych w UE: jak ułatwić rolnikom dostęp do gruntów?, „Studia Iuridica” 2018, t. 78, s. 102; eidem, Instrumenty prawne reglamentacji obrotu nieruchomościami rolnymi w Polsce na tle regulacji wybranych państw europejskich, „Studia Iuridica” 2017, t. 72, s. 87; B. Włodarczyk, Obrót nieruchomościami rolnymi w świetle traktatowej swobody przepływu kapitału-rozważania na gruncie orzecznictwa Trybunatu Sprawiedliwości Unii Europejskiej, „Przegląd Prawa Rolnego” 2019, nr 2, s. 37 i n.; P. Wojciechowski, Wybrane aspekty..., s. 25 i n.

47 Wyroki TSUE: z 6 marca 2018 r. w sprawach C-52/16 i C-113/16, SEGRO i Horváth, ECLI: EU:C:2018:157, pkt 51; z 6 listopada 1984 r. w sprawie 182/83, Fearon, EU:C:1984:335, pkt 7; z 23 września 2003 r. w sprawie C-452/01, Ospelt i Schlössle Weissenberg, EU:C:2003:493, pkt 24. $\mathrm{Na}$ temat tego ostatniego orzeczenia por. w szczególności: G. Holzer, Aktuelle Entwicklungen im landwirtschaftlichen Grundverkehrsrecht in Österreich, „Jahrbuch Agrarrecht” 2014, s. 235 i n.

${ }^{48}$ Dz. Urz. UE C 298 z 23.08.2018 r., s. 112-120.

49 Dz. Urz. UE C 350 z 18.10.2017 r., s. 5-20. 
nie swobodnego przepływu kapitału w rozumieniu art. 63 TFUE. Jednakże uregulowania krajowe mogą limitować swobodny przepływ kapitału z uwagi na „nadrzędne względy interesu ogólnego", takie jak: zachowanie tradycyjnej formy eksploatacji gruntów rolnych przez zagospodarowanie bezpośrednie oraz zapewnienie, by nieruchomości rolne były w większości zamieszkane i uprawiane przez ich właścicieli. Powołanie się na te względy nie jest jednak wystarczające do uznania legalności regulacji krajowych ograniczających swobodę przepływu kapitału, w przypadku gdy regulacje te nie spełniają jednego z trzech warunków: 1) stosowane są w sposób niedyskryminacyjny, 2) prowadzą do realizacji celu, jakiemu służą (wymóg adekwatności), 3) nie wykraczają poza zakres konieczny do jego osiągnięcia (wymóg proporcjonalności) ${ }^{50}$.

Uznając powyższe wskazówki za punkt wyjścia do dalszych analiz, należy odnieść je do przedstawionych wcześniej założeń restrykcyjnego kierunku wykładni art. 2 b u.k.u.r. Rozważając ten problem, można wyrazić pewne wątpliwości co do ich zgodności z prawem Unii Europejskiej.

Po pierwsze, szczególne zastrzeżenia może budzić nałożony na każdego - co do zasady - nabywcę nieruchomości rolnej, który w następstwie jej nabycia staje się, lub już jest, właścicielem (użytkownikiem wieczystym) nieruchomości rolnych o łącznej powierzchni co najmniej 1 ha, obowiązek prowadzenia gospodarstwa rolnego przez 5 lat od jej nabycia. Wymóg ten zgodnie z restrykcyjnym kierunkiem wykładni - oznacza, że nabywca taki powinien przez 5 lat wykonywać zawód rolnika w gospodarstwie rolnym, tj. pracować w nim oraz podejmować wszelkie decyzje dotyczące prowadzenia w gospodarstwie działalności wytwórczej w rolnictwie - bez względu na to, czy jego dotychczasowa aktywność zawodowa miała jakikolwiek związek z rolnictwem. Treści tego obowiązku można bronić, powołując się na wyżej opisane „nadrzędne względy interesu ogólnego”. Jednak już w sprawie Ospelt i Schlössle Weissenberg TSUE uznał tego typu regulację za godzącą w zasadę swobody przepływu kapitału i nieproporcjonalną z uwagi na wykroczenie poza zakres konieczny do osiągnięcia zamierzonego celu, tj. utrzymania rolniczego charakteru danego obszaru. Rozważania TSUE w ramach powołanego wyroku mają także znaczenie dla oceny legalności uregulowań wynikających z art. $2 \mathrm{~b}$ u.k.u.r. w kontekście sygnalizowanego wyżej dyskryminującego charakteru tych uregulowań dla sytuacji prawnej dzierżawców nieruchomości rolnych w Polsce ${ }^{51}$.

\footnotetext{
50 P. Wojciechowski, Wybrane aspekty..., s. 36-38.

51 Ibidem, s. 46.
} 
Warto ponadto zauważyć, że analiza legalności tej regulacji nie powinna być ograniczona wyłącznie do kwestii związanych z zasadą swobody przepływu kapitału. Powołany wyżej sposób interpretowania obowiązku (osobistego) prowadzenia gospodarstwa rolnego poprzez nadanie mu charakteru uniwersalnego pozwala wyrazić wątpliwość, czy polska regulacja nie narusza również praw podstawowych i wspólnych wartości Unii Europejskiej. Należy bowiem zwrócić uwagę, że obarczenie nabywcy obowiązkiem wykonywania zawodu rolnika, bez względu na jego dotychczasowe związki z rolnictwem, w następstwie samego faktu nabycia nieruchomości rolnej, może mieć wpływ na jego zdolność do prowadzenia innych działań zawodowych, a tym samym naruszać jego wolność prowadzenia działalności gospodarczej (art. 16 Karty praw podstawowych Unii Europejskiej). Nie można też wykluczyć, że obowiązek ten będzie miał wpływ na jego prawo do wykonywania swobodnie wybranego lub zaakceptowanego zawodu (art. 15 Karty praw podstawowych Unii Europejskiej).

Po drugie, w kwestii oceny legalności obowiązków nabywcy nieruchomości wynikających $\mathrm{z}$ art. $2 \mathrm{~b}$ u.k.u.r. w kontekście ograniczenia zasady swobody przepływu kapitału należy wskazać, że „rozłączne” i „niezależne” traktowanie obowiązków wynikających z ust. 1 i 2 tego artykułu można kwestionować z uwagi na adekwatność realizacji założonego celu, czyli przypuszczalnie - zachowania tradycyjnej formy eksploatacji gruntów rolnych przez zagospodarowanie bezpośrednie. W każdym bowiem przypadku, gdy nabywca nieruchomości rolnej nie staje się (lub nie jest) właścicielem (użytkownikiem wieczystym) nieruchomości rolnych o powierzchni co najmniej 1 ha wyłączony zostaje w sposób oczywisty obowiązek prowadzenia gospodarstwa rolnego. Trudno zatem uznać, że utrzymywanie zakazu zbywania lub oddawania w posiadanie takiej nieruchomości innym podmiotom prowadzi do realizacji wyżej powołanego celu.

Po trzecie, z uwagi na naruszenie wymogu proporcjonalności przyjętych ograniczeń może być z kolei kwestionowane utrzymywanie obowiązków wynikających $z$ art. $2 b$ u.k.u.r. w przypadku następczej utraty przez nabytą nieruchomość charakteru rolnego. W cytowanej rezolucji Parlamentu Europejskiego z 27 kwietnia 2017 r. podkreślono znaczenie instrumentów regionalnego i lokalnego planowania przestrzennego dla ,zachowania gruntów rolnych, zarządzania nimi i ich przekazywania”. Instrumenty planistyczne powinny być zatem decydujące dla tworzenia odrębnego reżimu obrotu nieruchomościami rolnymi. Nakładanie na właścicieli (użytkowników wieczystych) nieruchomości, które zostały uznane za zbędne na cele gospodarki rolnej mocą rozstrzygnięcia kompetentnych organów administracji publicz- 
nej (władzy planistycznej), nakazu ich rolniczego wykorzystania oraz zakazu ich zbywania lub oddawania w posiadanie innym podmiotom wydaje się wykraczać poza zakres konieczny do osiągnięcia celów uzasadniających ograniczenie swobody przepływu kapitału.

\section{Kwestia zgodności art. 2b u.k.u.r. z Konstytucją RP}

Liczne i dobrze uargumentowane wątpliwości co do zgodności z Konstytucją RP przepisów u.k.u.r. w brzmieniu ustalonym w 2016 r. zostały przedstawione w dwóch pismach Rzecznika Praw Obywatelskich (RPO) z 2016 r., tj. we wniosku z 11 lipca 2016 r. o stwierdzenie niezgodności z Konstytucją $\mathrm{RP}$ wybranych przepisów u.k.u.r. oraz w piśmie procesowym z 12 sierpnia 2016 r. Sprawa ta, oznaczona wspólną sygnaturą K 36/16, nadal czeka na rozstrzygnięcie. W powołanych pismach RPO wiele uwagi poświęcił kwestii konstytucyjności obowiązków nabywcy nieruchomości rolnej wynikających $\mathrm{z}$ art. $2 \mathrm{~b}$ ust. 1 i 2 u.k.u.r., wnosząc ostatecznie o stwierdzenie, że wymienione przepisy (jak również art. 9 ust. 1 pkt 2 i ust. 3 pkt 1 u.k.u.r.) są niezgodne $\mathrm{z}$ art. $2 \mathrm{w}$ zw. $\mathrm{z}$ art. 64 ust. 3 oraz art. 20, art. 21 ust. 1, art. 22 i art. 31 ust. 3 Konstytucji RP. Rezygnując z przytoczenia in extenso przedstawionych przez RPO argumentów na rzecz niekonstytucyjności tych regulacji, warto jednak podkreślić kilka z jego celnych spostrzeżeń, istotnych w kontekście prowadzonych rozważań na temat restrykcyjnego kierunku wykładni art. 2b ust. 1 i 2 u.k.u.r., zwłaszcza że nowelizacja u.k.u.r. dokonana w 2019 r. przyczyniła się do wzrostu praktycznego znaczenia tych regulacji.

Trudno nie zgodzić się z RPO, że redakcja art. 2 b ust. 1 i 2 u.k.u.r. nie czyni zadość zasadzie poprawnej (przyzwoitej, rzetelnej) legislacji, będącej jednym z przejawów państwa prawnego (art. 2 Konstytucji RP). Treść nałożonych na nabywcę nieruchomości rolnej obowiązków poprzez wykorzystanie szeregu nieokreślonych i niejasnych zwrotów, jak np. „prowadzenie gospodarstwa rolnego, w skład którego weszła nabyta nieruchomość", nie została sformułowana w jasny i precyzyjny sposób, dopuszczając wiele interpretacji ${ }^{52}$. Ma to bezpośredni wpływ na pewność prawa oraz przewidy-

52 Warto zwrócić uwagę na odmienne od upowszechnianego przez KOWR kierunku wykładni sposoby interpretacji obowiązków nabywcy nieruchomości rolnej proponowane w następujących publikacjach: A. Bieranowski. Uwagi ..., s. 112-114; A. Michnik, Obowiazki nabywcy ..., s. 105 i n.; P. Bender, Podstawowe problemy..., s. 44 i n.; K. Maj, Obowiazek prowadzenia gospodarstwa rolnego oraz zakaz zbywania i oddawania w posiadanie nieruchomości w ustawie o ksztaltowaniu ustroju rolnego - zagadnienia wybrane, „Krakowski Przegląd Notarialny” 2020, nr 1, s. 37 i n.; P. Blajer, Umowy działowe..., s. 53; idem, Umowa sprzedaży.., s. 120 i n. 
walność działań organów państwa, warunkując racjonalne prognozowanie działań uczestników obrotu. Zgodnie z poglądem wyrażonym przez Trybunał Konstytucyjny w wyroku z 14 czerwca 2000 r. $^{53}$, zasada bezpieczeństwa prawnego zakazuje przyjmowania nieprzewidywalnych unormowań, przy czym zaskakujące dla jednostki może być także stosowanie zawierających nieostre przesłanki, niejasnych, wieloznacznych przepisów, które nie pozwalają obywatelowi przewidzieć konsekwencji prawnych jego zachowań ${ }^{54}$.

Do zasady poprawnej legislacji nawiązują tezy wyrażone w wyroku z 12 stycznia 2000 r. $^{55}$, w którym Trybunał Konstytucyjny stwierdził, że „niedopuszczalne jest przyjmowanie w ustawie uregulowań blankietowych, pozostawiających organom władzy wykonawczej [...] swobodę normowania ostatecznego kształtu owych ograniczeń, a w szczególności wyznaczania zakresu tych ograniczeń". Stwierdzenia te są szczególnie ważne w kontekście rozważań na temat restrykcyjnego kierunku wykładni art. 2 b ust. 1 i 2 u.k.u.r., upowszechnianego przez KOWR, gdyż wyników tego kierunku wykładni nie da się pogodzić z efektami interpretacji dokonywanej według tradycyjnych metod (językowej, systemowej i funkcjonalnej), a jedynym argumentem na jego rzecz jest domniemana (niewynikająca wszakże z tekstu aktu prawnego) „wola ustawodawcy" ${ }^{56}$.

${ }^{53}$ Wyrok TK z 14 czerwca 2000 r., sygn. P 3/00, Dz. U. Nr 50, poz. 600.

${ }^{54}$ W kontekście zasad poprawnej legislacji sformułowanych w orzecznictwie TK na szczególną uwagę zasługuje okoliczność, że aktualnie największe znaczenie dla praktycznego stosowania regulacji u.k.u.r., w tym tych odnoszących się do unormowań obowiązków nabywcy nieruchomości rolnej, znacząco ingerujących w sferę praw i obowiązków jednostki, ma dokument o niejasnej kwalifikacji prawnej, tj. Wspólne stanowisko Ministerstwa Rolnictwa i Rozwoju Wsi, KOWR oraz Krajowej Rady Notarialnej z 27 lutego 2020 r. w sprawie stosowania w praktyce ustawy o kształtowaniu ustroju rolnego. Dokument ten nie dotyczy zresztą poruszanych tu kwestii, gdyż wymienione instytucje nie osiągnęły co do nich porozumienia.

${ }^{55}$ Wyrok TK z 12 stycznia 2000 r., sygn. P/11/98, Dz. U. Nr 3, poz. 46.

${ }^{56}$ Szerzej: P. Blajer, Umowa sprzedaży..., s. 120 i n. Należy zwrócić uwagę na szczególny sposób upowszechniania przez KOWR restrykcyjnego kierunku wykładni art. 2b u.k.u.r. Nie ma bowiem w tym względzie oficjalnego stanowiska tej instytucji, powszechnie dostępnego np. na jej stronie internetowej. O podstawowych założeniach tego kierunku wykładni uczestnicy obrotu informowani są najczęściej w czasie szkoleń i konferencji albo w drodze formalnych pism kierowanych np. do notariuszy lub sądów wieczystoksięgowych, kwestionujących dokonane czynności prawne pod względem ich zgodności z uznaną za obowiązującą interpretacją art. 2b u.k.u.r. Sama zaś wykładnia dokonywana przez KOWR również podlega zmianom, niezależnie od zmian stanu prawnego. Dla wielu uczestników poznańskiej konferencji „Obrót nieruchomościami rolnymi teoria i praktyka" dużym zaskoczeniem było z pewnością jednoznaczne stwierdzenie ze strony KOWR, że w przypadku zbycia nieruchomości rolnej na rzecz osoby bliskiej (a także na rzecz pozostałych podmiotów określonych w art. $2 \mathrm{~b}$ ust. 4 pkt 1) jej nabywca ma obowiązek prowadzenia gospodarstwa rolnego wynikający z art. $2 \mathrm{~b}$ ust. 1 u.k.u.r., któremu towarzyszy sankcja określona w art. 9 ust. 3 tego aktu prawnego. A zatem w rzeczywistości to organ władzy wykonawczej 
W obu powołanych pismach RPO kwestionuje ponadto proporcjonalność i adekwatność ograniczeń wynikających z art. $2 b$ u.k.u.r. Pod wieloma względami jego zarzuty konstytucyjne potwierdzają sygnalizowane wątpliwości co do zgodności art. $2 b$ u.k.u.r. z prawem Unii Europejskiej. W literaturze dostrzeżono także, iż analizowana regulacja stoi w sprzeczności z konstytucyjnymi założeniami, których realizacji powinien służyć proces kształtowania ustroju rolnego (art. 23 Konstytucji RP). Przesądza ona bowiem de facto o indywidualnym, a nie rodzinnym, sposobie prowadzenia gospodarstwa rolnego, pod rygorem następczego wywłaszczenia (zastosowania sankcji przewidzianej w art. 9 ust. 3 u.k.u.r. $)^{57}$. Jak się wydaje, regulacja ta powinna być także rozpatrywana pod kątem zgodności z art. 65 Konstytucji RP, zapewniającym każdemu wolność wyboru i wykonywania zawodu oraz wyboru miejsca pracy.

\section{Podsumowanie}

Wnioski płynące z przedstawionych rozważań na temat dominującego obecnie w praktyce obrotu restrykcyjnego kierunku wykładni art. 2 b u.k.u.r. zachęcają do sformułowania postulatu de lege ferenda o konieczności daleko idącej modyfikacji tej regulacji, a nawet jej eliminacji z systemu prawa w Polsce.

Stanowi ona, obok zawartej $\mathrm{w}$ art. 2 pkt 1 u.k.u.r. nieudanej definicji nieruchomości rolnej ${ }^{58}$, największe zagrożenie dla bezpieczeństwa obrotu

w sposób arbitralny i dyskrecjonalny zarazem nadaje ostateczny kształt ograniczeniom praw i wolności wynikających z art. $2 b$ u.k.u.r.

${ }^{57}$ P. Litwiniuk, Ochrona własności rolniczej w świetle ustawy o ksztaltowaniu ustroju rolnego, „Przegląd Prawa Rolnego” 2019, nr 2, s. 64.

${ }^{58}$ Sposób sformułowania tej definicji, wyznaczającej zakres stosowania przepisów u.k.u.r., należy uznać za podstawową przyczynę dysfunkcjonalności polskiego modelu obrotu nieruchomościami rolnymi (K. Marciniuk, Pojęcie nieruchomości rolnej jako przedmiotu reglamentacji obrotu własnościowego, „Studia Iuridica Lublinensia” 2017, nr 1, s. 93 i n.; Z. Truszkiewicz, Nieruchomość rolna i gospodarstwo rolne w rozumieniu u.k.u.r., „Krakowski Przegląd Notarialny” 2016, nr 2, s. 139 i n.; B. Wierzbowski, Pojęcie nieruchomości rolnej w prawie polskim, „Studia Iuridica Agraria” 2005, nr 4; P. Wojciechowski, Pojęcie nieruchomości rolnej, w: M. Korzycka (red.), Instytucje prawa rolnego, Warszawa 2019, s. 156 i n.). W kontekście związków tej definicji $\mathrm{z}$ regulacją dotyczącą obowiązków nabywcy nieruchomości rolnej wynikających z art. $2 \mathrm{~b}$ u.k.u.r. należy wskazać na niebezpieczeństwa związane z „ostrożnościowym” podejściem do tej definicji, polegającym na kwalifikacji danej nieruchomości jako rolnej w każdym wypadku, gdy istnieją wątpliwości co do jej statusu na płaszczyźnie u.k.u.r. (dotyczy to zwłaszcza nieruchomości o mieszanym charakterze). Bezrefleksyjne stosowanie tej metody postępowania skutkuje bowiem poważnymi konsekwencjami w postaci nieuzasadnionego objęcia nabywcy takiej nieruchomości nakazami i zakazami wynikającymi z art. 2 b u.k.u.r. 
nieruchomościami. Sposób interpretacji tej regulacji budzi też uzasadnione wątpliwości w kwestii jej konstytucyjności oraz zgodności z prawem Unii Europejskiej. Nie znajduje ona również dostatecznego uzasadnienia w argumentach komparatystycznych ${ }^{59}$.

Skoro jednak de lege lata normy wynikające $\mathrm{z}$ art. $2 \mathrm{~b}$ u.k.u.r. mają charakter obowiązujący, warto przypomnieć postulat Zygmunta Truszkiewicza, skierowany do sądów, by w procesie orzekania przestrzegały konstytucyjnej zasady proporcjonalności, tak interpretując przepisy u.k.u.r., aby jak najmniej ingerowały $\mathrm{w}$ relacje społeczne, $\mathrm{w}$ tym prywatnopraw$\mathrm{ne}^{60}$. Orzecznictwo sądów powszechnych dostarcza zresztą przykładów takiej racjonalnej interpretacji art. $2 \mathrm{~b}$ u.k.u.r. Na podkreślenie zasługują w tym względzie tezy przywołane w uzasadnieniu postanowienia Sądu Rejonowego w Wąbrzeźnie z 16 listopada 2018 r. ${ }^{61}$ Sąd zauważył w nim, że „ponieważ przepisy zawarte w u.k.u.r. w sposób oczywisty wkraczają w konstytucyjne prawa i wolności obywatelskie, w tym w prawo własności, i stanowią wyjątek od zasady swobodnego dysponowania własnością

59 Obowiązek prowadzenia działalności rolniczej na nabytej nieruchomości jest instrumentem stosunkowo rzadko stosowanym w ustawodawstwie rolnym państw europejskich (por. zawarty w niniejszym numerze „Przeglądu Prawa Rolnego” fragment raportu generalnego z obrad Komisji II podczas XXX Kongresu Europejskiego Komitetu Prawa Rolnego, Poznań 2019 „Obrót gruntami rolnymi w perspektywie komparatystycznej”). W sposób porównywalny do rozwiązań polskich został on zastosowany jedynie w węgierskim porządku prawnym. Należy jednak podkreślić różnice pomiędzy tymi dwiema krajowymi regulacjami. Rozwiązania węgierskie, choć można je kwestionować ze względu na proporcjonalność przyjętych ograniczeń, są dużo bardziej spójne niż polskie. Zastrzegają one bowiem prawo nabycia nieruchomości rolnych położonych w tym kraju wyłącznie na rzecz rolników (możliwości nabycia nieruchomości rolnych nie mają żadne jednostki organizacyjne). Skoro zatem nabyć nieruchomość rolną może wyłącznie wykwalifikowany rolnik, to nie ma przeszkód, by go obarczyć obowiązkiem prowadzenia działalności rolniczej na tej nieruchomości. W tym kontekście obowiązek ten jest logicznym następstwem istotnego przywileju, jaki stanowi sama możliwość nabycia nieruchomości rolnej. Por. Th. Ilgner, Die Beschränkungen der Rechte von Unionsbürgern auf Erwerb und Nutzung landwirtschaftlicher Flächen in Ungarn, „Europäische Zeitschrift für Wirtschaftsrecht” 2015, z. 3, s. 306; A. Raisz, Topical issues of the Hungarian land-transfer law purchasing and renting agricultural land: Legal framework and practical problems, ,Journal of Rural Law” 2017, nr 3, s. 71. Polska regulacja umożliwia tymczasem praktycznie wszystkim podmiotom nabywanie nieruchomości rolnych w rozumieniu u.k.u.r., tyle że za zgodą dyrektora generalnego KOWR wyrażoną w trybie art. $2 \mathrm{a}$ ust. 4 u.k.u.r. lub nawet bez tej zgody (w przypadku nieruchomości rolnych o powierzchni mniejszej niż 1 ha). W tym kontekście nakładanie obowiązku prowadzenia gospodarstwa rolnego na nabywców niemających dotąd żadnych związków z rolnictwem jest nieuzasadnione.

${ }^{60}$ Z. Truszkiewicz, Adekwatność instrumentów prawnych ksztaltowania ustroju rolnego, „Przegląd Prawa Rolnego” 2019, nr 2, s. 87.

${ }^{61}$ Wyrok Sądu Rejonowego w Wąbrzeźnie z 16 listopada 2018 r., sygn. I Ns 242/18, LEX nr 2623281 . 
należącej do istoty tego prawa zgodnie z art. 140 k.c., w szczególności art. 2 b ust. 1 i 2 u.k.u.r., ustanawiają de facto formę własności przymusowej, dlatego na wszystkie ograniczenia w dysponowaniu własnością należy patrzeć zawężająco i wskazane jest stosowanie wykładni pozwalającej w maksymalnym stopniu na zachowanie uprawnienia właścicielskiego do rozporządzania rzeczą”. W konsekwencji Sąd wywodzi, że „celowa interpretacja przepisów u.k.u.r., w szczególności obowiązków i zakazu zawartych w art. 2b ust. 1 i 2, wskazuje na konieczność zawężającego zakresu ich stosowania". W świetle przedstawionych rozważań przytoczone tezy należy uznać za w pełni racjonalne i uzasadnione.

\section{BIBLIOGRAFIA}

Bender P. (2019), Podstawowe problemy stosowania znowelizowanej ustawy o ksztaltowaniu ustroju rolnego (cz. II), „Rejent” $\mathrm{nr} 12$.

Bieluk J. (2019), Ustawa o ksztaltowaniu ustroju rolnego. Komentarz, Warszawa.

Bieranowski A. (2018), Komentarz do art. 166, teza 12, w: M. Fras, M. Habdas (red.), Kodeks cywilny. Komentarz, t. II: Własność i inne prawa rzeczowe (art. 126-352), Warszawa.

Bieranowski A. (2019), Uwagi o błędnym dekodowaniu zakazu zbywania własności nieruchomości rolnej, „Rejent” nr 8.

Blajer P.A. (2009), Koncepcja prawna rolnika indywidualnego w prawie polskim na tle porównawczym, Kraków.

Blajer P.A. (2015), Sasiedzkie prawo pierwokupu a struktura gruntowa polskich gospodarstw rolnych-panaceum czy pandemonium?, „Przegląd Prawa Rolnego” nr 2.

Blajer P.A. (2019), Umowa sprzedaży nieruchomości rolnej po wejściu w życie ustawy z dnia 26.04.2019 r. o zmianie ustawy o ksztaltowaniu ustroju rolnego oraz niektórych innych ustaw, „Rejent” nr 12.

Blajer P.A. (2019), Umowy działowe dotyczace nieruchomości rolnych po wejściu w życie ustawy z dnia 26 kwietnia 2019 r. o zmianie ustawy o ksztaltowaniu ustroju rolnego oraz niektórych innych ustaw, „Krakowski Przegląd Notarialny” nr 3.

Błahuta F., Piątowski J.S., Policzkiewicz J. (1967), Gospodarstwa rolne. Obrót, dziedziczenie, podziat, Warszawa.

Czechowski P. (2018), Obrót nieruchomościami rolnymi w świetle europejskiego soft law, „Studia Iuridica Agraria” t. XVI.

Czechowski P., Niewiadomski A. (2017), Instrumenty prawne reglamentacji obrotu nieruchomościami rolnymi w Polsce na tle regulacji wybranych państw europejskich, „Studia Iuridica"t. 72.

Czechowski P., Niewiadomski A. (2018), Mechanizmy prawne ochrony rolnego charakteru nieruchomości w świetle rezolucji Parlamentu Europejskiego z dnia 27 kwietnia 2017 r. $w$ sprawie aktualnego stanu koncentracji gruntów rolnych $w$ UE: jak ułatwić rolnikom dostęp do gruntów?, „Studia Iuridica” t. 78.

Gniewek E. (1978), Nabycie własności gruntów rolnych przez posiadaczy. Podstawowe zagadnienia ustawy o uregulowaniu własności gospodarstw rolnych, Wrocław. 
Ilgner Th. (2015), Die Beschränkungen der Rechte von Unionsbürgern auf Erwerb und Nutzung landwirtschaftlicher Flächen in Ungarn, „Europäische Zeitschrift für Wirtschaftsrecht" z. 3.

Litwiniuk P. (2019), Ochrona własności rolniczej w świetle ustawy o kształtowaniu ustroju rolnego, „Przegląd Prawa Rolnego” nr 2.

Łobos-Kotowska D. (2018), Komentarz do art. 553, teza 3, w: M. Fras, M. Habdas (red.), Kodeks cywilny. Komentarz, t. I:Część ogólna (art. 1-125), Warszawa.

Łobos-Kotowska D., Stańko M. (2019), Ustawa o kształtowaniu ustroju rolnego. Komentarz, Warszawa.

Maj K. (2020), Obowiązek prowadzenia gospodarstwa rolnego oraz zakaz zbywania i oddawania w posiadanie nieruchomości w ustawie o kształtowaniu ustroju rolnego-zagadnienia wybrane, „Krakowski Przegląd Notarialny” nr 1.

Marciniuk K. (2017), Pojęcie nieruchomości rolnej jako przedmiotu reglamentacji obrotu wtasnościowego, ,Studia Iuridica Lublinensia” nr 1.

Mataczyński M. (2004), W kwestii zgodności ustawy z 11 kwietnia 2003 r. o kształtowaniu ustroju rolnego z prawem europejskim w świetle orzecznictwa Europejskiego Trybunatu Sprawiedliwości, ,Rejent” nr 5.

Michnik A. (2017), Obowiązi nabywcy nieruchomości rolnej wynikające z ustawy z dnia 11 kwietnia 2003 r. o ksztaltowaniu ustroju rolnego, „Krakowski Przegląd Notarialny” $\mathrm{nr} 1$.

Paliwoda J. (1976), Problemy prawne uregulowania własności gospodarstw rolnych, Wrocław.

Piątowski J.S. (1971), Uregulowanie własności gospodarstw rolnych i zmiany w kodeksie cywilnym, „Państwo i Prawo” nr 8.

Raisz A. (2017), Topical issues of the Hungarian land-transfer law purchasing and renting agricultural land: Legal framework and practical problems, „Journal of Rural Law” nr 3.

Suchoń A. (2019), Pojęcie nieruchomości rolnej, gospodarstwa rolnego i działalności rolniczej w ustawie o ksztaltowaniu ustroju rolnego - wybrane kwestie z praktyki notarialnej, „Przegląd Prawa Rolnego" nr 2.

Truszkiewicz Z. (2016), Nieruchomość rolna i gospodarstwo rolne w rozumieniu u.k.u.r., „Krakowski Przegląd Notarialny” nr 2.

Truszkiewicz Z. (2019), Adekwatność instrumentów prawnych kształtowania ustroju rolnego, „Przegląd Prawa Rolnego" nr 2.

Wierzbowski B. (2005), Pojęcie nieruchomości rolnej w prawie polskim, „Studia Iuridica Agraria" t. IV.

Włodarczyk B. (2019), Obrót nieruchomościami rolnymi w świetle traktatowej swobody przepływu kapitału - rozważania na gruncie orzecznictwa Trybunału Sprawiedliwości Unii Europejskiej, „Przegląd Prawa Rolnego” nr 2.

Wojciechowski P. (2019), Pojęcie nieruchomości rolnej, w: M. Korzycka (red.), Instytucje prawa rolnego, Warszawa.

Wojciechowski P. (2019), Pojęcie rolnika, w: M. Korzycka (red.), Instytucje prawa rolnego, Warszawa.

Wojciechowski P. (2020), Wybrane aspekty ograniczenia obrotu nieruchomościami rolnymi $w$ prawie polskim $w$ kontekście unijnej zasady swobody przepływu kapitału, „Przegląd Prawa Rolnego" nr 2. 


\title{
LEGAL ISSUES CONNECTED WITH THE OBLIGATIONS OF A REAL ESTATE PURCHASER RESULTING FROM ARTICLE 2B OF THE ACT ON SHAPING THE AGRICULTURAL SYSTEM
}

\begin{abstract}
Sum mary
The aim of the considerations was to resolve doubts regarding the interpretation of the provision of Article 2b of the Act of 11 April 2003 on shaping the agricultural system. This provision imposes, in principle, two universal obligations on each acquirer of agricultural real estate (i) to run an agricultural holding contained in the agricultural real estate acquired, for a period of at least 5 years from the date of acquisition, or, in the case of a natural person, to run the holding personally, and (ii) not to dispose of the acquired real estate or give it in possession to other entities within the same 5-year period. The analysis of this provision enabled to identify many practical problems, and to formulate substantial reservations as to its compliance with the fundamental principles of the Constitution of the Republic of Poland and European Union law. As a consequence, de lege ferenda comments have been formulated, calling for a far-reaching modification of this regulation or its removal altogether from the Polish agricultural law system.
\end{abstract}

Keywords: agricultural real estate, purchase of agricultural real estate, obligations of the purchaser of agricultural real estate, agricultural holding, running an agricultural holding

\section{DELLE QUESTIONI GIURIDICHE RELATIVE AGLI OBBLIGHI CHE GRAVANO SUGLI ACQUIRENTI DEL TERRENO AGRICOLO AI SENSI DELL'ART. 2B DELLA LEGGE SUL REGIME AGRARIO}

\section{Riassunto}

L'articolo si propone di chiarire i dubbi sorti riguardo a come interpretare le disposizioni dell'art. 2 b della legge dell' 11 aprile 2002 sul regime agrario. Esse impongono due obblighi universali all'acquirente del terreno agricolo: l'ordine di gestire l'azienda agricola, parte del terreno acquisito, per un periodo di almeno 5 anni dalla data d'acquisto, e, nel caso l'acquirente sia una persona fisica, di farlo a titolo personale, nonché, sempre entro lo stesso periodo, il divieto di vendere oppure di cedere il terreno ad altri. L'analisi svolta ha permesso non solo di individuare molti problemi di natura pratica, ma anche di avanzare rilevanti obiezioni circa la conformità ai principi fondamentali della Costituzione della Repubblica di Polonia e del diritto dell'Unione europea. Di conseguenza, come osservazioni de lege ferenda, è stato formulato un postulato di dover apportare modifiche, di vasta portata, alla regolazione in oggetto, oppure di procedere a rimuoverla dall'ordinamento agricolo polacco nella sua totalità

Parole chiave: terreno agricolo, acquisto di terreno agricolo, obblighi degli acquirenti del terreno agricolo, azienda agricola, gestione di un'azienda agricola 